\title{
TARGETING TUMOUR CELL INVASION AND DISSEMINATION IN VIVO BY AN APTAMER THAT INHIBITS UROKINASE-TYPE PLASMINOGEN ACTIVATOR THROUGH A NOVEL MULTI- FUNCTIONAL MECHANISM
}

\author{
Kenneth A. Botkjaer ${ }^{1,2}$, Elena I. Deryugina ${ }^{3}$, Daniel M. Dupont ${ }^{1,2}$, Henrik Gårdsvoll ${ }^{2,4}$, Erin \\ M. Bekes ${ }^{3}$, Cathrine K. Thuesen ${ }^{1,2}$, Zhou Chen ${ }^{1,2,5}$, Michael Ploug ${ }^{2,4}$, James P. Quigley ${ }^{3}$, \\ and Peter A. Andreasen ${ }^{1,2}$ \\ ${ }^{1}$ Department of Molecular Biology and Genetics, Aarhus University, Denmark ${ }^{2}$ Danish-Chinese \\ Centre for Proteases and Cancer (www.proteasesandcancer.dk) ${ }^{3}$ Department of Cell Biology, \\ The Scripps Research Institute, La Jolla, USA ${ }^{4}$ Finsen Laboratory, Rigshospitalet and Biotech \\ Research \& Innovation Centre, Copenhagen, Denmark ${ }^{5}$ Fujian Institute of Research on the \\ Structure of Matter, Chinese Academy of Sciences, Fuzhou
}

\begin{abstract}
Data accumulated over the latest two decades have established that the serine protease urokinasetype plasminogen activator (uPA) is a potential therapeutic target in cancer. When designing inhibitors of the proteolytic activity of serine proteases, obtaining sufficient specificity is problematic since the topology of the proteases' active sites are highly similar. In an effort to generate highly specific uPA inhibitors with new inhibitory modalities, we isolated uPA-binding RNA aptamers by screening a library of 35 nucleotides long $2^{\prime}$-fluoro-pyrimidine RNA molecules using as bait a version of human pro-uPA lacking the epidermal growth factor-like and kringle domains. One pro-uPA binding aptamer sequence, referred to as upanap-126, proved to be highly specific for human uPA. Upanap-126 delayed the proteolytic conversion of human pro-uPA to active uPA, but did not inhibit plasminogen activation catalysed by two-chain uPA. The aptamer also inhibited the binding of pro-uPA to uPAR and the binding of vitronectin to the preformed pro-uPA/uPAR complexes both in cell-free systems and on cell surfaces. Furthermore, upanap-126 inhibited human tumour cell invasion in vitro, in the Matrigel assay, and in vivo, in the chick embryo assay of cell escape from microtumours. Finally, upanap-126 significantly reduced the levels of tumour cell intravasation and dissemination in the chick embryo model of spontaneous metastasis. Together, our findings demonstrate that utilisation of upanap-126 represents a novel multi-functional mechanistic modality for inhibition of uPA-dependent processes involved in tumour cell spread.
\end{abstract}

\section{Keywords}

zymogen; cancer; metastasis; serine protease; urokinase-type plasminogen activator receptor

Corresponding author: Peter A. Andreasen; Gustav Wieds vej 10C, Aarhus C, DK-8000; Tel: +45 87155456; Fax: +45 86123178; pa@mb.au.dk.

Conflicts of interest: There are no conflicts of interest to disclose 


\section{INTRODUCTION}

The urokinase-type plasminogen activator (uPA) is an extracellular serine protease playing a central role in tissue remodelling events occurring in normal physiology and in pathophysiology, including cancer invasion and metastasis. uPA catalyses the conversion of the extracellular zymogen plasminogen to the active matrix-degrading protease plasmin. uPA itself is secreted as a zymogen, pro-uPA, and is activated by the cleavage of a single peptide-bond between residues Lys158 and Ile159. The cleavage can be catalysed by several proteases, including plasmin [1]. uPA consists of an epidermal growth factor-like domain (EGF-domain, residues 5-46) and a kringle domain (residues 50-131), which together comprise the amino-terminal fragment (ATF), followed by an interdomain linker (residues 132-147), and the catalytic domain (residues 148-411). uPA is recruited to cell surfaces via high affinity interaction of the EGF-domain with the glycosylphosphatidylinositol (GPI)anchored uPA receptor, uPAR. Since plasminogen also accumulates on cell surfaces, via lysine binding sites in its kringle domains, the cell surface provides an efficient template for plasminogen activation. Furthermore, binding of uPA to uPAR create a pro-adhesive effect by increasing the binding of uPAR to the extracellular matrix protein vitronectin [2]. Ligation of UPAR with vitronectin has in turn been found to initiate cytoskeletal rearrangements [3].

Several lines of experimental evidence link uPA with the invasive capacity of malignant tumours: uPA levels positively correlate with the invasive potential of different cell lines; prevention of UPA from binding to uPAR decreases invasion; antibodies and antisense oligonucleotides to uPA reduce metastasis of tumour cells in both mice and chick embryo models; mice lacking either the uPA or the plasminogen gene show lower incidence of metastasis than wild type mice [4] [for reviews see[1, 5-7]]. The basic hypothesis is, that uPA secreted by cancer cells or stromal cells catalyses generation of plasmin, which in turn facilitates cancer cell invasion into surrounding tissues directly, by degrading the basement membrane and ECM proteins or indirectly, by activating other pro-enzymes such as promatrix metalloproteases (pro-MMPs). However, uPA-promoted tumour spread involves also other activities, including adhesive interactions of the uPA/uPAR complex with vitronectin [8], cellular signalling mediated by uPA binding to uPAR [9, 10], and uPA-induced generation of plasmin, which then mediates activation of growth factors [11] or cleaves cell surface survival molecules $[12,13]$.

Almost 25 years ago, it was shown that breast cancer patients with high levels of uPA in their tumours have a significantly shorter disease-free interval and shortened overall survival than patients having tumours with low levels of uPA [14, 15]. In the case of breast cancer, so-called level I evidence studies supported the independent prognostic value of combined measurements of uPA and PAI-1 levels [16, 17]. Based on such studies, the American Society of Clinical Oncology and the German Breast Cancer Society recommend the use of uPA and PAI-1 as prognostic markers in breast cancer patients [18, 19]. High levels of uPA also correlate with aggressive disease in most other types of cancers [20]. Measurements of uPAR levels are also of prognostic value [21].

Since uPA represents a potential therapeutic target in cancer, a number of small molecule uPA inhibitors have been developed [5, 22]. However, most of these inhibitors lack sufficiently documented specificity. In order to generate highly specific uPA inhibitors, we have turned to nucleic acid aptamers, which consist of RNA or single-stranded DNA. They are selected during an iterative in vitro process named "Systematic Evolution of Ligands by Exponential enrichment" (SELEX) [23, 24]. The selection of oligonucleotides, which bind specifically and with high affinity to a target, is based on the ability of these molecules to fold into specific three-dimensional structures. In the SELEX procedure, a library of $10^{14}$ 
$10^{15}$ different oligonucleotide sequences are subjected to a target and binding sequences enriched over 6-18 iterative cycles. Several properties of aptamers make them suitable as drug candidates. They display dissociation constants $\left(K_{D}\right)$ in the low to sub-nanomolar range. They are reported to be virtually non-toxic and non-immunogenic. They can be modified chemically to obtain desired blood clearance and biodistribution patterns. One aptamer against vascular endothelial growth factor (VEGF) has been approved by FDA for treatment of age-related macular degeneration and several others are in clinical trials primarily for use as anticoagulants [25-27].

Here we describe an RNA aptamer, upanap-126 (uPA nucleic acid aptamer-126), that has been selected with a truncated version of human pro-uPA (residues 134-411) as a bait. The aptamer inhibits plasmin-mediated pro-uPA activation, competes the binding of pro-uPA to uPAR and prevents the binding of pro-uPA/uPAR complex to vitronectin. Upanap-126 was tested in several cell function assays in vitro and the potency of the aptamer was demonstrated in vivo in tumour invasion and intravasation model systems.

\section{METHODS AND MATERIALS}

\section{Proteins and reagents}

Human soluble uPAR lacking the glycolipid anchor (residues 1-283) and a human pro-uPA variant (residues 134-411, S356A) lacking the EGF- and kringle domains were produced in Drosophila cells as described for uPA lacking the EGF-domain (residues 45-411) [28]. The ATF (residues 1-135) of uPA was prepared by proteolytic cleavage of active uPA [29]. The EGF-domain of human uPA (residues 1-48) was a kind gift from Dr. Steven Rosenberg [30]. Recombinant human pro-uPA was generously provided by Abbott laboratories (Abbott Park, IL, USA). Glu-plasminogen purified from human plasma was a kind gift from Lars Sottrup-Jensen (Aarhus University, Denmark). Plasmid DNA encompassing the coding sequence for mutant T7 polymerase Y639F was generously donated by Dr. Rui Sousa (University of Texas Health Science Center, San Antonio, Texas, USA). T7 polymerase Y639F was expressed in BL21 Escherichia coli cells and purified by ammonium sulphate precipitation followed by SP-sepharose chromatography. The following reagents were purchased from the indicated sources: Human uPA (Wakamoto, Tokyo, Japan); mouse uPA and human $\mathrm{a}_{2}$-antiplasmin (Molecular Innovations); Human tPA (Genentech); H-D-ValLeu-Lys- $p$-nitroanilide (S-2251) and H-D-Glu-Gly-Arg-p-nitroanilide (S-2444)

(Chromogenix); H-D-Val-Leu-Lys-7-amido-4-methylcoumarine (VLK-AMC, I-1390) (Bachem Bioscience); aprotinin from bovine lung (Sigma-Aldrich); multimeric human vitronectin (BD Biosciences); monoclonal antibody to mouse uPA clone H77A10 (Molecular Innovations). The following in-house produced antibodies and peptide were used: Monoclonal anti-uPA mAb-6 [31] and mAb-112 [32]; monoclonal anti-uPAR mAbR2 [33]; polyclonal anti-human uPA F1609 [34] affinity purified using a human uPAcoupled Sepharose column; and mupain-1 peptide [35].

\section{Selection of aptamers binding to the catalytic domain of UPA}

Systematic evolution of ligands by exponential enrichment (SELEX) was carried out as described [36] with minor modifications. The RNA library was constructed with a 35nucleotide degenerate sequence and with $2^{\prime}$-fluor-pyrimidines as described [37] using the primers 5'-CGCGGATCCTAATACGACTCACTATAGGGGCCACCAACGACATT-3' containing the $\mathrm{T} 7$ promoter sequence and $5^{\prime}$ -

GATCCATGGGCACTATTTATATCAAC $\left(\mathrm{N}_{35}\right)$ AATGTCGTTGGTGGCCC-3' containing the degenerate sequence. Enrichment of RNA aptamers with binding affinity towards the truncated version of human pro-uPA (residues 134-411), lacking the EGF and kringle domains and harbouring the mutation S356A, was carried out by capturing the protein target 
on protein A-coupled Sepharose beads using the rabbit polyclonal anti-uPA antibody F1609 [34] essentially as described [37] with 12 rounds of enrichments. To obtain 2 '-fluoropyrimidine modified RNA molecules, RNA transcriptions were carried out using $2.5 \mathrm{mM}$ each of ATP and GTP (GE Healthcare), and $2.5 \mathrm{mM}$ each of 2'-F-dCTP and 2'-F-dUTP ( $2^{\prime}$-F-Y, TriLink Biotechnologies) and $50 \mu \mathrm{g} / \mathrm{mL}$ mutant T7 RNA polymerase Y639F. Selected RNA aptamer clones were transcribed from dsDNA generated by Klenow extension of primers constructed from the individual sequences. RNA aptamers were purified on $8 \%$ denaturing polyacrylamide gels followed by micro gel filtration columns (micro Bio-spin 30 column, Biorad) exchanging the buffer to $10 \mathrm{mM}$ HEPES, $140 \mathrm{mM}$ $\mathrm{NaCl}, 2 \mathrm{mM} \mathrm{MgCl} 2$, $\mathrm{pH}$ 7.4. 2' $-\mathrm{F}-\mathrm{Y}$ RNA concentrations were determined by UV spectroscopy at $260 \mathrm{~nm}\left(1 \mathrm{~A}_{260}\right.$ unit $\left.=40 \mathrm{mg} / \mathrm{mL}\right)$.

\section{Surface plasmon resonance analysis of aptamer binding}

For surface plasmon resonance analysis, a Biacore T200 instrument (GE Healthcare) was used. Pro-uPA or ATF was captured on a CM5 chip coupled with the same polyclonal antiuPA antibody F1609 [34], which was used for aptamer selections. Then, the selected aptamer clones were passed over the chip at $200 \mathrm{nM}$ for $60 \mathrm{sec}$ at $30 \mu \mathrm{l} / \mathrm{min}$. Running buffer was $10 \mathrm{mM}$ HEPES, $\mathrm{pH} 7.4,140 \mathrm{mM} \mathrm{NaCl}$ (HBS), containing $2 \mathrm{mM} \mathrm{MgCl} 2,0.05 \%$ tween-20, and $0.1 \%$ BSA. Regeneration of the surface between each run was carried out using $10 \mathrm{mM}$ acetic acid, $\mathrm{pH} 2.7,0.5 \mathrm{M} \mathrm{NaCl}$ for $25 \mathrm{sec}, 30 \mu \mathrm{l} / \mathrm{min}$ followed by $10 \mathrm{mM}$ glycine, $\mathrm{pH} 2.1$ for $25 \mathrm{sec}, 30 \mu \mathrm{l} / \mathrm{min}$. The capture level of pro-uPA and ATF did not vary significantly between running cycles indicating that the surface remained stable to the regeneration conditions. The previously described monoclonal antibodies mAb-112, binding the uPA catalytic domain [32], and mAb-6, binding the uPA ATF [38], were used as positive controls for binding.

Alternatively, a monoclonal antibody to mouse uPA, clone H77A10, that binds in the ATF, was captured on a chip coupled with anti-mouse-IgG, after which mouse uPA was injected to a final level of approximately $1500 \mathrm{RU}$. Then, aptamer clones were injected over the surface at $500 \mathrm{nM}$ for $60 \mathrm{sec}$ at $30 \mu \mathrm{l} / \mathrm{min}$, and with regeneration between each run using 10 $\mathrm{mM}$ glycine, $\mathrm{pH} 1.7$ for $180 \mathrm{sec}$ at $10 \mu \mathrm{l} / \mathrm{min}$. The previously described mupain-1 peptide binding the catalytic domain of mouse uPA was used as positive control for binding [35].

\section{In vitro enzyme assays}

Coupled plasminogen activation assays with and without cells, direct pro-uPA activation assays, and pro-uPA cleavage assays analysed by SDS-PAGE and immunoblotting were carried out essentially as described [39] in HBS containing $0.1 \%$ BSA and $2 \mathrm{mM} \mathrm{MgCl} 2$. For pro-uPA activation assays, data were fit to a 4-parameter logistic nonlinear regression model yielding the $I C_{50}$-values for inhibition of pro-uPA activation (equation 1):

$$
y=\min +\frac{(\max -\min )}{1+\left(\frac{x}{C_{50}}\right)} \quad \text { (equation 1) }
$$

For analysing the relative amounts of single-chain pro-uPA and activated two-chain uPA generated in PC-hi/diss cell cultures, cells were grown in presence of $0.5 \mu \mathrm{M}$ upanap-126 or control RNA sequence. Following 48 hours, conditioned medium samples were collected and analysed by reducing SDS-PAGE and immunoblotting with rabbit polyclonal anti-uPA antibody F1609 [34]. 


\section{Surface plasmon resonance analysis of UPA-UPAR binding}

Anti-uPAR monoclonal antibody mAb-R2 was immobilised onto a CM5 sensor chip and soluble uPAR was captured to approximately $130 \mathrm{RU}$ by injecting $5 \mathrm{nM}$ uPAR over the surface for 120 seconds at a flow rate of $10 \mu \mathrm{l} / \mathrm{min}$. Pro-uPA, active uPA or the isolated ATF $(10 \mathrm{nM})$ was run in the absence or presence of aptamers (0-200 nM) over the surface at a flow rate of $10 \mu \mathrm{l} / \mathrm{min}$ for 30 seconds. The sensor chip was regenerated with $0.1 \mathrm{M}$ acetic acid, $0.5 \mathrm{M} \mathrm{NaCl}, \mathrm{pH} 2.7$ for 15 seconds at $30 \mu \mathrm{l} / \mathrm{min}$. Data were fit to a 4-parameter logistic nonlinear regression model (equation 1) as described above. To ensure that the binding capacity of the sensor chip was not reduced between each cycle due to the repetitive regeneration, the binding of pro-uPA, active uPA or ATF without aptamers was repeated in the end of each experiment. This analysis was found to give rise to the same binding levels as before the competition experiment was started.

\section{Solid-phase assay for binding of pro-uPA-UPAR complex to vitronectin}

Human multimeric vitronectin $(0.5 \mu \mathrm{g} / \mathrm{ml})$ was coated onto Maxisorp microtitre plates (Nunc). Upanap-126, the control RNA sequence or PAI-1 were individually added at a final concentration of $1 \mu \mathrm{M}$ to $0.1 \mu \mathrm{M}$ preformed pro-uPA-uPAR complex in PBS containing $0.01 \%$ tween 20 and $2 \mathrm{mM} \mathrm{MgCl}_{2}$. The mixtures were incubated for 30 minutes at room temperature, before being added to the vitronectin coated wells. The relative amounts of prouPA-uPAR bound to vitronectin were determined with anti-uPAR antibody mAb-R2, followed by Horse-radish-peroxidase-conjugated rabbit-anti-mouse IgG (Dako).

\section{Lamellipodia formation assay}

The assay was done as described previously [28]. Briefly, HEK293 cells were seeded in 24well culture plates onto vitronectin-coated glass coverslips. The stable clone of HEK293 cells expressing a single-site mutant of human uPAR, uPAR ${ }_{W 32 A}$, was used and cultured as described [28]. At the day of experiment, new culture medium containing $20 \mathrm{nM}$ human pro-uPA or the isolated EGF-domain in the presence or absence of various concentrations of upanap-126 or control RNA sequence were added to the cells. After 24 hours, evaluation of lamellipodia-positive cells was carried out as described [28].

\section{Matrigel invasion assay}

Cell invasion assays in vitro and in vivo were performed with PC-hi/diss cells [40]. In Matrigel invasion assays, the upper side of membranes $(8 \mu \mathrm{m}$ pore Transwell, Fisher Scientific) was pre-coated with $2 \mu \mathrm{g}$ Matrigel (BD Biosciences). Conditioned medium from chicken embryonic fibroblasts (CM-CEF) was used as a chemoattractant in the lower chamber. $1 \times 10^{5} \mathrm{PC}$-hi/diss cells were plated in $100 \mu \mathrm{l}$ of SF-DMEM atop Matrigel in the upper chamber. Upanap-126 or control RNA sequence was added to both the upper and lower chambers at a final concentration of $1 \mu \mathrm{M}$, along with additionally supplemented 2 $\mathrm{mM} \mathrm{MgCl}$. Following 48 hour incubation, the invaded PC-hi/diss cells were detached with trypsin/EDTA from the underside of the inserts, combined with non-adherent cells from the lower chamber, and counted.

\section{Intramesodermal microtumour model}

Escape from microtumours and invasion of PC-hi/diss cells in vivo was carried out in live chick embryos as described [41]. Briefly, PC-hi/diss cells were labelled with CellTracker Green CMFDA (Molecular Probes, Invitrogen) and injected into the mesoderm layer of the chorioallantoic membrane (CAM) of 9-day-old chicken embryos. On day 2 after cell injections, developing microtumours were treated topically with $25 \mu 1$ Dulbecco's PBS (DPBS), supplemented with $5 \mu \mathrm{M}$ of upanap-126 or control RNA sequence, 5\% dimethyl sulfoxide (DMSO) and $2 \mathrm{mM} \mathrm{MgCl}_{2}$. On day 6 , embryos were injected intravenously with 
rhodamine-conjugated Lens culinaris lectin (LCA; VectorLabs, Burlingame, CA) to highlight the vasculature, and portions of the CAM containing microtumours were excised and immediately imaged in the fluorescence microscope. Quantification of invasion distances was carried out as described [41]. A total of 15-20 microtumours from 3-5 embryos were analysed for each variable.

\section{The chick embryo model for tumour cell dissemination}

Analysis of spontaneous intravasation and dissemination of PC-hi/diss cells carried out in chick embryos was as described [40]. Briefly, SPAFAS White Leghorn embryos (Charles River, North Franklin, CT) were allowed to develop in a humidified $37^{\circ} \mathrm{C}$ incubator. After 10 days of incubation, $2.5 \times 10^{6} \mathrm{PC}$-hi/diss cells were grafted through the window in the egg shell onto the CAM of each embryo. On days 2 and 4 after cell grafting, developing primary tumours were treated topically with $100 \mu \mathrm{l}$ DPBS supplemented with $2.5 \mu \mathrm{M}$ upanap-126 or control RNA sequence, $5 \%$ DMSO and $2 \mathrm{mM} \mathrm{MgCl}_{2}$. On day 7, primary tumours were removed and weighed, and portions of the CAM distal to the site of primary tumour development were excised and analysed by $A l u$-qPCR to determine actual numbers of human cells in the chicken tissue, essentially as described [40].

\section{RESULTS}

\section{Selection of RNA aptamers targeting the serine protease domain of pro-uPA}

SELEX was performed with the uPA catalytic domain containing part of the interdomain linker region (residues 134-411) in the inactive single-chain zymogen form and with the active site Ser356 mutated to alanine. Eighty-four clones from the pool of enriched aptamers obtained by 12 selection rounds were sequenced and found to contain 9 different RNA sequences (Table I).

\section{Identification of aptamers that inhibit the plasminogen activation activity initiated by pro- uPA}

Effects of the selected RNA aptamers on plasminogen activation were assessed in an assay in which pro-uPA or active uPA was incubated with plasminogen and the amount of generated plasmin evaluated by cleavage of a chromogenic substrate S-2251. Of the 9 sequences analysed, two aptamers, i.e. upanap-126 and upanap-231, were found to be inhibitory in the setting requiring pro-uPA activation for generation of plasmin (Figure 1A). None of the aptamers inhibited in the plasminogen activation assay when active uPA was incubated together with plasminogen, indicating that the effect of the upanap-126 and upanap-231 aptamers was on pro-uPA activation rather than directly on uPA-mediated plasminogen activation (Figure 1B). A non-uPA-binding RNA sequence had no inhibitory effects on plasmin generation and was used as a negative control (Figure 1, A and B).

In surface plasmon resonance analysis, the two inhibitory aptamers were found to bind full length human pro-uPA and active uPA with half maximal binding occurring at approximately $50-100 \mathrm{nM}$ for both aptamers (data not shown). Accurate $K_{D}$ determinations could not be made due to biphasic dissociation kinetics. In the same SPR format, no measurable binding of the aptamers to isolated human ATF could be demonstrated, confirming that the binding site for upanap-126 resides in the SPD (data not shown). As the inhibition and binding levels of upanap-126 and upanap-231 were highly similar, upanap-126 was selected as a representative for further characterisation since this clone was the most abundant among sequenced clones after 12 rounds of selection (Table I). As demonstrated in Figure 1C, the inhibitory effects of upanap-126 were dose-dependent with a substantial reduction of generated plasmin activity in the range of 1 to $100 \mathrm{nM}$ aptamer. Importantly, upanap-126 displayed no measurable binding to mouse uPA or inhibition of 
plasminogen activation when catalysed by human tissue-type plasminogen activator, tPA (data not shown).

\section{Mechanism of inhibition of the plasminogen activation activity of uPA by upanap-126}

We next evaluated the inhibitory mechanisms of upanap-126 in a more direct manner. First, its ability to inhibit pro-uPA activation was assessed. To this end, pro-uPA was incubated with plasmin for a period of time after which further plasmin activity was quenched by the addition of aprotinin. The amount of active uPA generated was estimated from the rate of hydrolysis of the small chromogenic uPA peptide substrate S-2444. The addition of upanap-126 inhibited pro-uPA activation with an $I C_{50}$-value of $7.3 \mathrm{nM} \pm 0.3 \mathrm{nM}$, whereas the control RNA sequence had no effect (Figure 2A). Importantly, no effect of upanap-126 on uPA-mediated hydrolysis of S-2444 was observed (data not shown).

To directly analyse if the aptamers influenced the rate of cleavage of single-chain pro-uPA, plasmin was incubated with pro-uPA in the presence or absence of upanap-126 or control RNA sequence for various time periods after which reaction products were visualised by reducing SDS-PAGE and immunoblotting. Upanap-126 significantly delayed the rate of plasmin-catalysed cleavage of pro-uPA, whereas a control RNA sequence showed no effect (Figure 2B).

\section{Effects of upanap-126 on the binding of UPA to UPAR}

In a surface plasmon resonance (SPR) setting, pro-uPA, active uPA and ATF were analysed for binding to uPAR captured on a CM5 sensor chip in the presence or absence of aptamers. The association of pro-uPA to uPAR was inhibited by upanap- 126 with an $I C_{5 \sigma}$-value of $19.2 \pm 3.4 \mathrm{nM}$, whereas a control RNA sequence showed no effect (Figure 3A). Active uPA was also inhibited from binding to uPAR, albeit with a higher $I C_{50}$-value of $306 \pm 125 \mathrm{nM}$. Importantly, upanap-126 had no effect on the binding of purified ATF to uPAR, confirming that the binding site of upanap-126 is located in the serine protease domain (Figure 3A).

\section{Effects of upanap-126 on binding of the uPA-uPAR complex to vitronectin}

We analysed if upanap-126 could interfere with the binding of the uPA-uPAR complex to vitronectin, using an enzyme-linked immunosorbent assay (ELISA), in which vitronectin was coated onto the solid phase and the binding of the preformed pro-uPA-uPAR complex in the presence or absence of aptamers was analysed. Upanap-126 decreased the binding between pro-uPA-uPAR complex and vitronectin (Figure 3B). PAI-1 was used as a positive control for inhibition of the interaction between pro-uPA-uPAR and vitronectin since PAI-1 binds the somatomedin B domain of vitronectin in the same position as UPAR [42]. Passing upanap-126 over a SPR sensor surface with pro-uPA captured on immobilised UPAR showed that upanap-126 was unable to induce dissociation of the uPA-uPAR complex. In contrast, upanap-126 was observed to bind the pro-uPA-uPAR complex although with a clearly reduced affinity as compared to binding to pro-uPA captured by the polyclonal antibody F1609 (data not shown). These observations confirm that upanap-126 binds the preformed pro-uPA-uPAR complex directly and must shield the complex from binding to vitronectin, rather than causing the effect by inducing dissociation of uPA from uPAR. The reduced affinity for uPAR-bound pro-uPA also explains the higher $I C_{50}$-value observed for upanap-126 towards this interaction compared with the values observed for the effects towards pro-uPA activation and uPA-uPAR interaction.

\section{Upanap-126 is an effective inhibitor of UPA-dependent processes on the cell surface}

To evaluate the effect of upanap-126 on cell-surface associated, uPA-catalysed plasminogen activation, we monitored plasmin activity after addition of plasminogen and pro-uPA to 
U937 cells, which express high levels of uPAR. In order only to score generation of plasmin at the cell surface, the assay was performed in the presence of $a_{2}$-antiplasmin, which rapidly inhibits plasmin in solution, but is ineffective against cell-surface associated plasmin. The inhibitory profile of upanap-126 on plasmin generation observed in a cell-free system (Figure 1A), was recapitulated with U937 cells (Figure 4A, black triangles). As expected, no plasmin activity was generated in the absence of cells (Figure 4A, black squares), whereas high plasmin levels were generated in the presence of cells (Figure 4A, black circles). Importantly, the non-binding control RNA sequence showed no inhibition (Figure $4 \mathrm{~A}$, open circles). We also found that upanap-126 was able to inhibit plasminogen activation initiated by active two-chain uPA on the surface of U937 cells (data not shown) whereas no inhibition was observed in the absence of cells (Figure 1B). This observation demonstrates the uPA-uPAR inhibitory activity of upanap-126 at the cellular level.

To evaluate a direct effect of aptamers on the pro-adhesive uPA-uPAR interaction with vitronectin in a cellular context, a newly adapted protrusion assay was employed [28]. In this assay, lamellipodia formation induced by uPAR-vitronectin binding is scored. In HEK293 cells expressing wild type uPAR, lamellipodia formation occurs uPAindependently. In contrast, in cells expressing the single-site mutant $\mathrm{uPAR}_{\mathrm{W} 32 \mathrm{~A}}$ (HEK$\mathrm{uPAR}_{\mathrm{W} 32 \mathrm{~A}}$ ), lamellipodia formation is uPA dependent, as the mutation weakens the interaction between $\mathrm{uPAR}$ and vitronectin. Lamellipodia formation by HEK-uPAR $\mathrm{W}_{32 \mathrm{~A}}$ cells can therefore be rescued by addition of catalytically inactive pro-uPA $\mathrm{S}_{356 \mathrm{~A}}$ or even the isolated EGF-domain of uPA [28]. This assay is thus suitable for evaluating whether uPA antagonists, which are able to disrupt the binding of uPA to uPAR or uPA-uPAR complexes to vitronectin, would affect lamellipodia formation. The presence of upanap-126 caused inhibition of lamellipodia formation induced by pro-uPA $\mathrm{S}_{\mathrm{S} 56 \mathrm{~A}}$ in $\mathrm{HEK}_{-\mathrm{uPAR}} \mathrm{W}_{32 \mathrm{~A}}$ cells (Figure 4B). However, in apparent agreement with its binding to the serine protease domain of pro-uPA, $1 \mu \mathrm{M}$ upanap-126 (i.e. a concentration that caused a substantial decrease in pro$\mathrm{uPA}_{\mathrm{S} 356 \mathrm{~A}}$-induced lamellipodia formation) did not inhibit lamellipodia formation rescued by the isolated uPA EGF-domain. The control RNA sequence showed no inhibition of lamellipodia formation in $\mathrm{uPAR}_{\mathrm{W} 32 \mathrm{~A}}$-expressing cells induced by either pro-uPA or uPA EGF-domain (Figure 4B).

\section{Human tumour cell invasion in vitro and in vivo is inhibited by upanap-126}

Next, we investigated the ability of upanap-126 to interfere with human tumour cell invasion. We used a highly disseminating variant of human PC-3 prostate carcinoma, i.e. PC-hi/diss cells, generated by in vivo selection [40]. Dissemination of this cell variant in chick embryo and mouse model systems has previously been shown to depend on the uPA system $[40,41]$. When PC-hi/diss cells were cultured in the presence of $500 \mathrm{nM}$ upanap-126, the amount of active uPA generated was substantially decreased (Figure 4C). Correspondingly, the addition of $1 \mu \mathrm{M}$ upanap-126 resulted in a significant reduction of tumour cell invasion in the Matrigel invasion assay (Figure 4D). The control RNA sequence showed no effect in these assays (Figure $4 \mathrm{C}$ and D).

To evaluate the inhibitory effects of upanap-126 on tumour cell invasion in vivo, we employed a newly developed model, in which fluorescently-labelled tumour cells are inoculated into the CAM mesoderm of chick embryos developing ex ovo. Cell escape from intramesodermal microtumours and invasion into surrounding stroma are then visualised microscopically 5-6 days after cell injections [41]. In the present study, treatment of developing PC-hi/diss microtumours with $25 \mu \mathrm{l}$ of a $5 \mu \mathrm{M}$ solution of upanap-126 caused a $50 \%$ reduction in stromal invasion of tumour cells as compared to treatment with control RNA sequence (Figure 5). 
Finally, we investigated whether upanap-126 would inhibit spontaneous dissemination of PC-hi/diss cells in the chick embryo model for tumour cell metastasis. In this model, human tumour cells are grafted atop the CAM, a highly vascularised tissue that supports growth of primary tumours and also provides vascular conduits for tumour cell intravasation and dissemination [40, 41]. The developing PC-hi/diss tumours were treated topically with 100 $\mu \mathrm{l}$ of a $2.5 \mu \mathrm{M}$ solution of aptamers and 7 days after grafting, the actual numbers of human cells that disseminated to the distal CAM were quantified by Alu-qPCR. Upanap-126 dramatically inhibited PC-hi/diss cell intravasation by more than $80 \%$, but did not affect significantly the growth of the primary tumours (Figure 6).

\section{DISCUSSION}

The results presented in this study show that targeting functional exosites of uPA provides a conceptual and practical alternative to standard inhibition of proteolytic activity by targeting the enzyme's active site. In this regard, upanap-126 inhibits plasminogen activation at the very apex of the activation cascade, i.e. by delaying the proteolytic activation of pro-uPA. Moreover, upanap-126 inhibits other molecular interactions of pro-uPA, i.e., the association of pro-uPA to uPAR, and the subsequent binding of the pro-uPA-uPAR complex to vitronectin. These inhibitory effects were observed in both cell-free model systems and cell functional assays. In contrast, upanap-126 does not inhibit plasminogen activation catalysed by active uPA, and shows no measurable effect on uPA-mediated hydrolysis of a small chromogenic peptide substrate. Furthermore, upanap-126 efficiently inhibits uPA-dependent cellular invasion in both cell culture and live animal settings.

Upanap-126 appears to be highly specific for human uPA over other serine proteases. First of all, upanap-126 only inhibited plasminogen activation initiated using human pro-uPA and not when using the other plasminogen activator, human tissue-type plasminogen activator. Secondly, upanap-126 does not bind measurably to mouse uPA, which is more similar to human uPA than any human homologous protease. Considering that upanap-126 must bind to the SPD it is not surprising that the aptamer inhibits pro-uPA activation. However, it is unexpected that upanap-126 inhibits interactions distant from the SPD, i.e., uPAR binding to the EGF-domain of uPA, as well as vitronectin binding to uPAR, an interaction induced by uPA-uPAR complex formation. The observation can be explained by the fact that although RNA aptamers have relatively low molecular masses, they actually have relatively large dimensions compared to their target proteins, as evident from published X-ray crystal structures of proteins in complex with RNA aptamers. Thus, a thrombin-binding RNA aptamer with molecular mass of $8 \mathrm{kDa}$ had maximum length of about $45 \AA$ A. Comparably, human thrombin has a molecular mass of $36 \mathrm{kDa}$ and a maximum length of approximately $55 \AA$ A [43]. Similarly, an aptamer against an $\mathrm{IgG}_{1} \mathrm{Fc}$-fragment with molecular mass of $8 \mathrm{kDa}$ had maximum length of about $45 \AA$, while the $\mathrm{IgG}_{1} \mathrm{Fc}$-fragment has a molecular weight of $50 \mathrm{kDa}$ and a maximum length of approximately $70 \AA$ [44]. With a molecular mass for upanap- 126 of about $26 \mathrm{kDa}$, its length may well approach $100 \AA$, which should be sufficient to cover a region from the primary binding site in the uPA SPD up to its EGFdomain [45]. The observation that upanap-126 inhibits the binding of pro-uPA to uPAR with a lower $I C_{50}$ than the binding of active two-chain uPA to uPAR (Figure $3 \mathrm{~A}$ ) could be caused by a slightly differential affinity of upanap- 126 for pro-uPA versus active uPA or differences in the interaction of pro-uPA and active uPA with uPAR. Previously, we showed that $\mathrm{UPA}$ acquire an increased overall interdomain flexibility upon conversion of pro-uPA to active uPA [45].

By using full-length human uPA as a target, we previously selected RNA aptamers, which were all directed against the ATF of uPA [37]. Similar to upanap-126, several of the ATFbinding aptamers were found to inhibit the uPA-uPAR interaction [37]. In addition, we also 
generated and characterised a murine monoclonal antibody, mAb-112, capable of inhibiting pro-uPA activation [32]. Like upanap-126, mAb-112 delays the proteolytic activation of pro-uPA. By interfering with zymogen activation and receptor binding, upanap-126 combines the two inhibitory mechanisms displayed individually by the ATF-binding aptamers [37] and the pro-uPA activation-blocking mAb-112 [32]. Additionally, upanap-126 inhibits the binding of the preformed pro-uPA-uPAR complex to vitronectin, a modality that to the best of our knowledge has not been observed with any other compounds.

Both in the in vitro and in vivo assays, the inhibitory activities displayed by upanap-126 were found to lead to efficient inhibition of uPA-mediated tumour cell invasion and dissemination. For invasion experiments, we used a variant of the human prostate carcinoma PC-3 cell line, PC-hi/diss, selected in vivo for high disseminating potential. The uPA activity was shown to be central for the increased dissemination of this cell variant and the inhibition of pro-uPA activation by mAb-112 significantly decreased intravasation levels of PC-hi/diss cells in the CAM and mouse xenograft models [40]. Recently, it was elucidated that it was the initial escape of PC-hi/diss cells from the primary tumour and tumour cell invasion into the surrounding stroma that were facilitated by active uPA during tumour cell spontaneous dissemination [41]. Herein, upanap-126 was found to reduce PC-hi/diss invasion in a Matrigel assay in vitro. Importantly, upanap-126 was also inhibitory for PC-hi/ diss cell escape and stromal invasion in vivo. Furthermore, upanap-126 substantially reduced intravasation and vascular dissemination of PC-hi/diss cells to secondary sites in the chick embryo model, thereby validating the inhibitory potential of this novel pro-uPA binding aptamer in live animals.

The inhibition of pro-uPA activation, preventing plasminogen conversion to active plasmin, is likely to be the primary cause for the reduction of human tumour cell invasion displayed by upanap-126 in the chick embryo, similarly to what has been found for mAb-112 [40]. However, it has been demonstrated that the interaction between uPA and its cell-surface receptor uPAR is necessary for an increased invasive potential of the human cell lines $\mathrm{HeLa}$ and Wish in the CAM model [46]. Therefore, the role of upanap-126 in vivo might be dual, i.e. via inhibition of both receptor binding and plasminogen activation both mechanisms increasing tumour dissemination. Further experiments would be needed to unravel this point. By stable silencing uPA in the PC-hi/diss cells combined with the expression of mutant uPA's lacking the uPAR binding site or the activation site, the mechanism of upanap-126 in vivo could possibly be clarified. In addition, upanap-126's ability to inhibit the interaction of uPA-complexed uPAR to vitronectin in the chick embryo models remains a subject for future verification. When uPAR interacts with vitronectin, it initiates actin reorganisation and increases cell motility [3]. Blocking this interaction could therefore lead to reduced cell migration. Importantly, the binding site for UPAR in the somatomedin B domain of vitronectin is very well conserved between human and chick vitronectins and human UPAR on the surface of PC-hi/diss cells is likely able to bind to chicken vitronectin in the live embryo model systems.

Aptamers targeting functional exosites of proteases have previously been described (reviewed in [25]). Thus, aptamers inhibiting the binding of co-factors tissue factor and FVa to coagulation factors FVIIa and FXa, respectively, were shown to interfere with coagulation [47, 48]. Aptamers inhibiting more than one functional characteristic of their targets have also been described. Thus, a thrombin binding aptamer, named HD-1, inhibited prothrombin activation [49], thrombin-catalysed fibrin clot formation, and thrombincatalysed cleavage of PAR-1 [50]. However, these functional events of thrombin were all related to binding of substrates and co-factors to the same exosite I, whereas binding of upanap-126 affects multiple different functional sites of pro-uPA. 
In conclusion, we have generated a novel uPA inhibiting RNA aptamer, upanap-126, selected against the serine protease domain and part of the linker region. Functional characterisation of upanap-126 demonstrated that this aptamer inhibits uPA-mediated activities through multiple molecular mechanisms. The multi-faceted mode of functional inhibition was demonstrated to be efficient in reducing uPA-mediated tumour cell invasion and dissemination in several in vitro and in vivo model systems, thereby highlighting the utility of simultaneously targeting several functional exosites of the pro-uPA molecule.

\section{Acknowledgments}

The authors thank Anni Christensen and Chenxing Li for their excellent technical support.

Financial support: This work was supported by grants from the Danish Cancer Society (DP 07043, DP 08001, R40-A1838); the Danish National Research Foundation (26-331-6); the Carlsberg Foundation (2010-01-0819); the National Natural Science Foundation of China (30811130467, 30973567, 30770429); the Danish Research Agency (272-06-0518); the Novo Nordisk Foundation (R114-A11382); the National Institutes of Health R01 CA 129484 and 105412 and NIH/National Centre for Research Resources/Scripps Translational Science Institute grant UL1 RR025774; and National Institutes of Health National Cancer Institute training grant 5T 32CA077109.

\section{Abbreviations}

ATF

CAM

EGF-domain

GPI

HBS

PBS

DPBS

MMP

SPD

tPA

UPA

UPAR amino-terminal fragment

chorioallantoic membrane

epidermal growth factor-like domain

glycosylphosphatidylinositol

HEPES-buffered saline

phosphate-buffered saline

Dulbecco's PBS

matrix metalloproteinase

serine protease domain

tissue-type plasminogen activator

urokinase-type plasminogen activator

urokinase-type plasminogen activator receptor

\section{References}

1. Andreasen PA, Egelund R, Petersen HH. The plasminogen activation system in tumor growth, invasion, and metastasis. Cell Mol Life Sci. 2000; 57(1):25-40. [PubMed: 10949579]

2. Wei Y, Waltz DA, Rao N, Drummond RJ, Rosenberg S, Chapman HA. Identification of the urokinase receptor as an adhesion receptor for vitronectin. J Biol Chem. 1994; 269(51):3238032388. [PubMed: 7528215]

3. Kjoller L, Hall A. Rac mediates cytoskeletal rearrangements and increased cell motility induced by urokinase-type plasminogen activator receptor binding to vitronectin. J Cell Biol. 2001; 152(6): 1145-1157. [PubMed: 11257116]

4. Shapiro RL, Duquette JG, Roses DF, Nunes I, Harris MN, Kamino H, et al. Induction of primary cutaneous melanocytic neoplasms in urokinase-type plasminogen activator (uPA)-deficient and wild-type mice: cellular blue nevi invade but do not progress to malignant melanoma in uPAdeficient animals. Cancer Res. 1996; 56(15):3597-3604. [PubMed: 8758932] 
5. Carriero MV, Stoppelli MP. The urokinase-type plasminogen activator and the generation of inhibitors of urokinase activity and signaling. Current pharmaceutical design. 2011; 17(19):19441961. [PubMed: 21711235]

6. Dano K, Behrendt N, Hoyer-Hansen G, Johnsen M, Lund LR, Ploug M, et al. Plasminogen activation and cancer. Thromb Haemost. 2005; 93(4):676-681. [PubMed: 15841311]

7. Ulisse S, Baldini E, Sorrenti S, D’Armiento M. The urokinase plasminogen activator system: a target for anti-cancer therapy. Curr Cancer Drug Targets. 2009; 9(1):32-71. [PubMed: 19200050]

8. Kriegbaum MC, Persson M, Haldager L, Alpizar-Alpizar W, Jacobsen B, Gardsvoll H, et al. Rational targeting of the urokinase receptor (UPAR): development of antagonists and non-invasive imaging probes. Current drug targets. 2011; 12(12):1711-1728. [PubMed: 21707479]

9. Blasi F, Sidenius N. The urokinase receptor: focused cell surface proteolysis, cell adhesion and signaling. FEBS letters. 2010; 584(9):1923-1930. [PubMed: 20036661]

10. Smith HW, Marshall CJ. Regulation of cell signalling by uPAR. Nat Rev Mol Cell Biol. 2010; 11(1):23-36. [PubMed: 20027185]

11. Shanmukhappa K, Matte U, Degen JL, Bezerra JA. Plasmin-mediated proteolysis is required for hepatocyte growth factor activation during liver repair. The Journal of biological chemistry. 2009; 284(19):12917-12923. [PubMed: 19286661]

12. Fazioli F, Resnati M, Sidenius N, Higashimoto Y, Appella E, Blasi F. A urokinase-sensitive region of the human urokinase receptor is responsible for its chemotactic activity. EMBO J. 1997; 16(24): 7279-7286. [PubMed: 9405357]

13. Casar B, He Y, Iconomou M, Hooper JD, Quigley JP, Deryugina EI. Blocking of CDCP1 cleavage in vivo prevents Akt-dependent survival and inhibits metastatic colonization through PARP1mediated apoptosis of cancer cells. Oncogene. 2011

14. Duffy MJ, O’Grady P, Devaney D, O’Siorain L, Fennelly JJ, Lijnen HJ. Urokinase-plasminogen activator, a marker for aggressive breast carcinomas. Preliminary report. Cancer. 1988; 62(3):531533. [PubMed: 3134120]

15. Duffy MJ, Reilly D, O’Sullivan C, O’Higgins N, Fennelly JJ, Andreasen P. Urokinaseplasminogen activator, a new and independent prognostic marker in breast cancer. Cancer research. 1990; 50 (21):6827-6829. [PubMed: 2119883]

16. Janicke F, Prechtl A, Thomssen C, Harbeck N, Meisner C, Untch M, et al. Randomized adjuvant chemotherapy trial in high-risk, lymph node-negative breast cancer patients identified by urokinase-type plasminogen activator and plasminogen activator inhibitor type 1. J Natl Cancer Inst. 2001; 93(12):913-920. [PubMed: 11416112]

17. Look MP, van Putten WL, Duffy MJ, Harbeck N, Christensen IJ, Thomssen C, et al. Pooled analysis of prognostic impact of urokinase-type plasminogen activator and its inhibitor PAI-1 in 8377 breast cancer patients. J Natl Cancer Inst. 2002; 94(2):116-128. [PubMed: 11792750]

18. Harris L, Fritsche H, Mennel R, Norton L, Ravdin P, Taube S, et al. American Society of Clinical Oncology 2007 update of recommendations for the use of tumor markers in breast cancer. J Clin Oncol. 2007; 25(33):5287-5312. [PubMed: 17954709]

19. Sturgeon CM, Duffy MJ, Stenman UH, Lilja H, Brunner N, Chan DW, et al. National Academy of Clinical Biochemistry laboratory medicine practice guidelines for use of tumor markers in testicular, prostate, colorectal, breast, and ovarian cancers. Clin Chem. 2008; 54(12):e11-79. [PubMed: 19042984]

20. Schmitt M, Mengele K, Napieralski R, Magdolen V, Reuning U, Gkazepis A, et al. Clinical utility of level-of-evidence-1 disease forecast cancer biomarkers uPA and its inhibitor PAI-1. Expert Rev Mol Diagn. 2010; 10(8):1051-1067. [PubMed: 21080821]

21. Lund IK, Illemann M, Thurison T, Christensen IJ, Hoyer-Hansen G. uPAR as anti-cancer target: evaluation of biomarker potential, histological localization, and antibody-based therapy. Current drug targets. 2011; 12(12):1744-1760. [PubMed: 21707477]

22. Rockway TW, Nienaber V, Giranda VL. Inhibitors of the protease domain of urokinase-type plasminogen activator. Current pharmaceutical design. 2002; 8(28):2541-2558. [PubMed: 12369939]

23. Ellington AD, Szostak JW. In vitro selection of RNA molecules that bind specific ligands. Nature. 1990; 346(6287):818-822. [PubMed: 1697402] 
24. Tuerk C, Gold L. Systematic evolution of ligands by exponential enrichment: RNA ligands to bacteriophage T4 DNA polymerase. Science. 1990; 249(4968):505-510. [PubMed: 2200121]

25. Dupont DM, Andersen LM, Botkjaer KA, Andreasen PA. Nucleic Acid Aptamers Against Proteases. Curr Med Chem. 2011

26. Nimjee SM, Rusconi CP, Harrington RA, Sullenger BA. The potential of aptamers as anticoagulants. Trends Cardiovasc Med. 2005; 15(1):41-45. [PubMed: 15795162]

27. Pestourie C, Tavitian B, Duconge F. Aptamers against extracellular targets for in vivo applications. Biochimie. 2005; 87(9-10):921-930. [PubMed: 15963620]

28. Gardsvoll H, Jacobsen B, Kriegbaum MC, Behrendt N, Engelholm L, Ostergaard S, et al. Conformational regulation of urokinase receptor function: impact of receptor occupancy and epitope-mapped monoclonal antibodies on lamellipodia induction. J Biol Chem. 2011; 286(38): 33544-33556. [PubMed: 21799009]

29. Egelund R, Petersen TE, Andreasen PA. A serpin-induced extensive proteolytic susceptibility of urokinase-type plasminogen activator implicates distortion of the proteinase substrate-binding pocket and oxyanion hole in the serpin inhibitory mechanism. Eur J Biochem. 2001; 268(3):673685. [PubMed: 11168406]

30. Stratton-Thomas JR, Min HY, Kaufman SE, Chiu CY, Mullenbach GT, Rosenberg S. Yeast expression and phagemid display of the human urokinase plasminogen activator epidermal growth factor-like domain. Protein Eng. 1995; 8(5):463-470. [PubMed: 8532668]

31. Grondahl-Hansen J, Ralfkiaer E, Nielsen LS, Kristensen P, Frentz G, Dano K. Immunohistochemical localization of urokinase- and tissue-type plasminogen activators in psoriatic skin. J Invest Dermatol. 1987; 88(1):28-32. [PubMed: 3098860]

32. Blouse GE, Botkjaer KA, Deryugina E, Byszuk AA, Jensen JM, Mortensen KK, et al. A novel mode of intervention with serine protease activity: targeting zymogen activation. J Biol Chem. 2009; 284(7):4647-4657. [PubMed: 19047064]

33. Ronne E, Behrendt N, Ellis V, Ploug M, Dano K, Hoyer-Hansen G. Cell-induced potentiation of the plasminogen activation system is abolished by a monoclonal antibody that recognizes the NH2-terminal domain of the urokinase receptor. FEBS Lett. 1991; 288(1-2):233-236. [PubMed: 1715292]

34. Knoop A, Andreasen PA, Andersen JA, Hansen S, Laenkholm AV, Simonsen AC, et al. Prognostic significance of urokinase-type plasminogen activator and plasminogen activator inhibitor-1 in primary breast cancer. Br J Cancer. 1998; 77(6):932-940. [PubMed: 9528837]

35. Andersen LM, Wind T, Hansen HD, Andreasen PA. A cyclic peptidylic inhibitor of murine urokinase-type plasminogen activator: changing species specificity by substitution of a single residue. Biochem J. 2008; 412(3):447-457. [PubMed: 18318660]

36. Kenan DJ, Keene JD. In vitro selection of aptamers from RNA libraries. Methods Mol Biol. 1999; 118:217-231. [PubMed: 10549525]

37. Dupont DM, Madsen JB, Hartmann RK, Tavitian B, Duconge F, Kjems J, et al. Serum-stable RNA aptamers to urokinase-type plasminogen activator blocking receptor binding. RNA. 2010; 16 (12): 2360-2369. [PubMed: 20962041]

38. Petersen HH, Hansen M, Schousboe SL, Andreasen PA. Localization of epitopes for monoclonal antibodies to urokinase-type plasminogen activator: relationship between epitope localization and effects of antibodies on molecular interactions of the enzyme. Eur J Biochem. 2001; 268(16): 4430-4439. [PubMed: 11502203]

39. Botkjaer KA, Fogh S, Bekes EC, Chen Z, Blouse GE, Jensen JM, et al. Targeting the autolysis loop of urokinase-type plasminogen activator with conformation-specific monoclonal antibodies. The Biochemical journal. 2011; 438(1):39-51. [PubMed: 21635223]

40. Conn EM, Botkjaer KA, Kupriyanova TA, Andreasen PA, Deryugina EI, Quigley JP. Comparative analysis of metastasis variants derived from human prostate carcinoma cells: roles in intravasation of VEGF-mediated angiogenesis and uPA-mediated invasion. Am J Pathol. 2009; 175(4):16381652. [PubMed: 19729488]

41. Bekes EM, Deryugina EI, Kupriyanova TA, Zajac E, Botkjaer KA, Andreasen PA, et al. Activation of Pro-uPA Is Critical for Initial Escape from the Primary Tumor and Hematogenous Dissemination of Human Carcinoma Cells. Neoplasia. 2011; 13(9):806-821. [PubMed: 21969814] 
42. Deng G, Curriden SA, Wang S, Rosenberg S, Loskutoff DJ. Is plasminogen activator inhibitor-1 the molecular switch that governs urokinase receptor-mediated cell adhesion and release? J Cell Biol. 1996; 134(6):1563-1571. [PubMed: 8830783]

43. Long SB, Long MB, White RR, Sullenger BA. Crystal structure of an RNA aptamer bound to thrombin. RNA. 2008; 14(12):2504-2512. [PubMed: 18971322]

44. Nomura Y, Sugiyama S, Sakamoto T, Miyakawa S, Adachi H, Takano K, et al. Conformational plasticity of RNA for target recognition as revealed by the 2.15 A crystal structure of a human IgG-aptamer complex. Nucleic Acids Res. 2010; 38(21):7822-7829. [PubMed: 20675355]

45. Behrens MA, Botkjaer KA, Goswami S, Oliveira CL, Jensen JK, Schar CR, et al. Activation of the zymogen to urokinase-type plasminogen activator is associated with increased interdomain flexibility. Journal of molecular biology. 2011; 411(2):417-429. [PubMed: 21669207]

46. Ossowski L. In vivo invasion of modified chorioallantoic membrane by tumor cells: the role of cell surface-bound urokinase. J Cell Biol. 1988; 107(6 Pt 1):2437-2445. [PubMed: 2848851]

47. Buddai SK, Layzer JM, Lu G, Rusconi CP, Sullenger BA, Monroe DM, et al. An anticoagulant RNA aptamer that inhibits proteinase-cofactor interactions within prothrombinase. J Biol Chem. 2010; 285(8):5212-5223. [PubMed: 20022942]

48. Rusconi CP, Yeh A, Lyerly HK, Lawson JH, Sullenger BA. Blocking the initiation of coagulation by RNA aptamers to factor VIIa. Thromb Haemost. 2000; 84(5):841-848. [PubMed: 11127866]

49. Kretz CA, Stafford AR, Fredenburgh JC, Weitz JI. HD1, a thrombin-directed aptamer, binds exosite 1 on prothrombin with high affinity and inhibits its activation by prothrombinase. $\mathrm{J}$ Biol Chem. 2006; 281(49):37477-37485. [PubMed: 17046833]

50. Boncler MA, Koziolkiewicz M, Watala C. Aptamer inhibits degradation of platelet proteolytically activatable receptor, PAR-1, by thrombin. Thromb Res. 2001; 104(3):215-222. [PubMed: $11672764]$ 
A

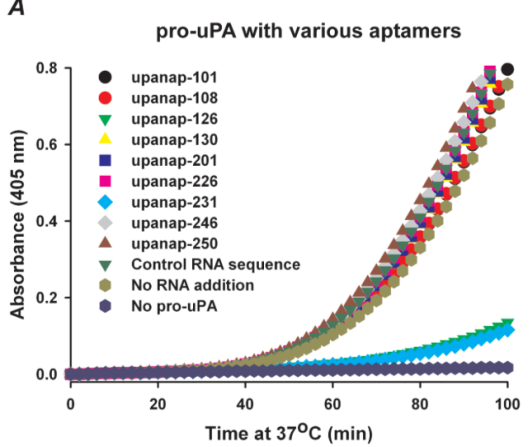

$B$

uPA with various aptamers
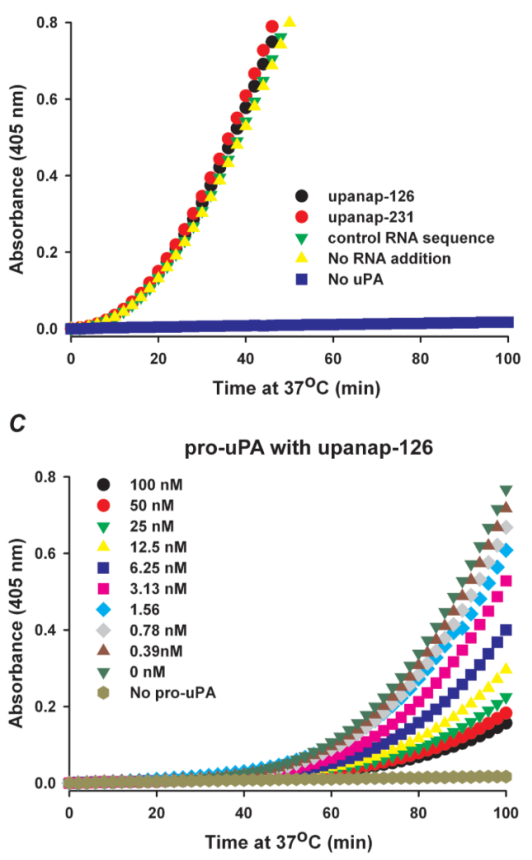

FIGURE 1. Selected aptamers inhibit in vitro plasminogen activation initiated by pro-uPA Pro-uPA $(\boldsymbol{A}$ and $\boldsymbol{C})$ or active uPA $(\boldsymbol{B})$ were pre-incubated at $0.25 \mathrm{nM}$ with $200 \mathrm{nM}$ of the indicated aptamers $(\boldsymbol{A}$ and $\boldsymbol{B})$, or various concentrations of upanap-126 $(\boldsymbol{C})$. Following preincubation, plasminogen was added to $30 \mathrm{nM}$ and the chromogenic plasmin substrate, $\mathrm{S}-2251$, to $0.5 \mathrm{mM}$. Plasmin generation was followed at $37^{\circ} \mathrm{C}$ by the hydrolysis of the chromogenic substrate, as measured by the increase of absorbance at $405 \mathrm{~nm}$. Samples containing no pro-uPA or uPA, or containing control RNA sequence or no RNA served as negative controls. 

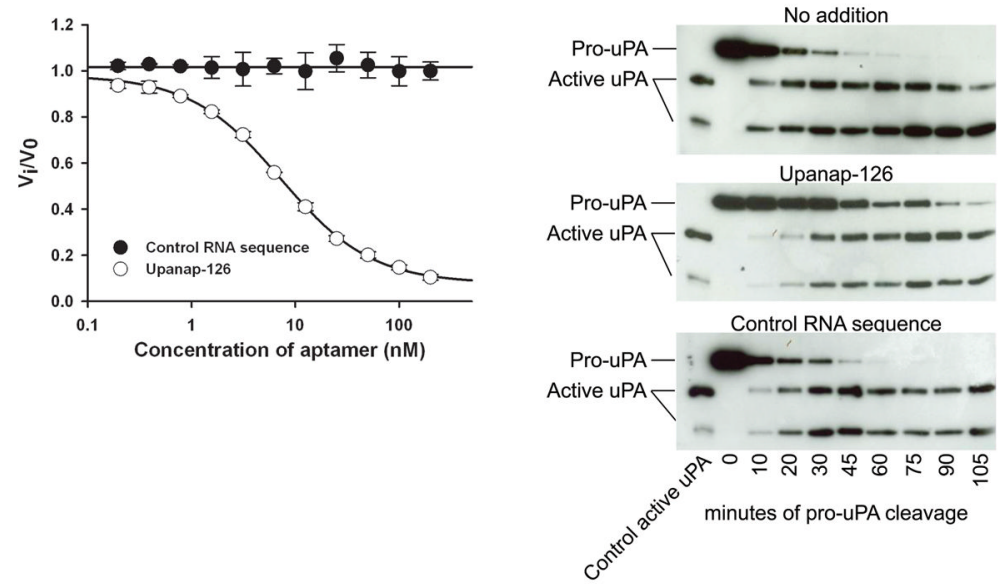

FIGURE 2. Upanap-126 inhibits plasmin-catalysed pro-uPA activation

$\boldsymbol{A}$, Pro-uPA ( $2 \mathrm{nM}$ ) was pre-incubated with various concentrations of a control RNA (black circles) or upanap-126 (open circles). At time zero, $0.5 \mathrm{nM}$ plasmin was added, followed by incubation for 12 minutes at room temperature after which time the activity of plasmin was quenched with $0.2 \mu \mathrm{M}$ aprotinin. The amount of generated active uPA was measured by the rate of hydrolysis of uPA substrate S-2444. $\boldsymbol{B}$, Pro-uPA (100 nM) was pre-incubated without additions, or with upanap-126 or a control RNA sequence $(200 \mathrm{nM})$ for $30 \mathrm{~min}$. Then, 2.5 $\mathrm{nM}$ plasmin was added to the reaction mixtures (time zero). Samples were taken at different time points and analysed by reducing SDS-PAGE and immunoblotting using anti-uPA polyclonal antibody F1609. 
A

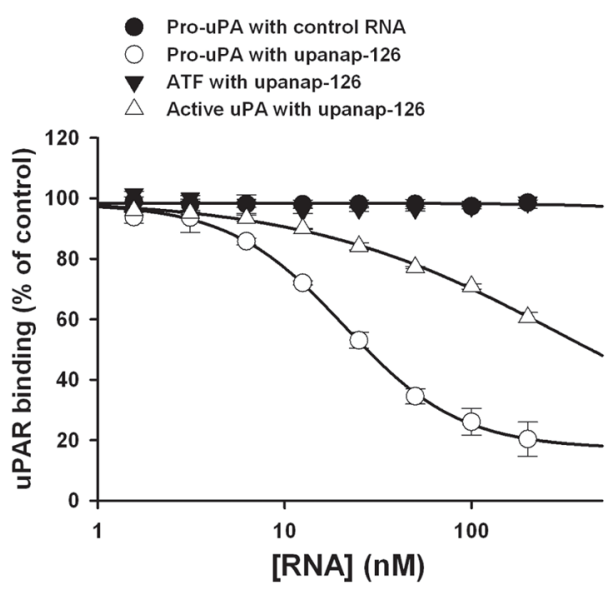

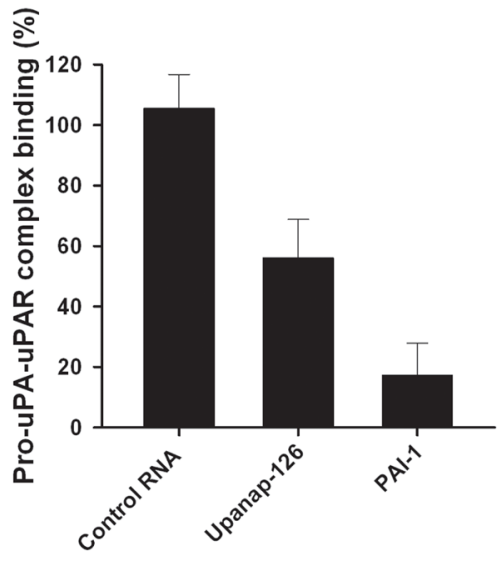

FIGURE 3. Effects of upanap-126 on molecular interactions of uPA and uPAR

$\boldsymbol{A}$, Increasing concentrations of upanap-126 (0-200 nM) were pre-incubated with $10 \mathrm{nM}$ of pro-uPA (open circles), active uPA (open triangles) or ATF (black triangles), whereas control RNA (0-200 nM) was pre-incubated with $10 \mathrm{nM}$ pro-uPA (black circles). The mixtures were then passed over the UPAR-immobilised CM5 chip in a BIACORE T200 instrument and the amounts of pro-uPA, active UPA or ATF bound to UPAR in the presence of upanap-126 or control RNA were calculated. $\boldsymbol{B}$, Vitronectin was coated onto the solid phase of 96-well plates. The wells were incubated with preformed pro-uPA-uPAR complex $(0.1 \mu \mathrm{M})$ in the absence or presence of upanap-126, control RNA or PAI-1 at a concentration of $1 \mu \mathrm{M}$. Bound pro-uPA-uPAR complex was detected with an anti-uPAR antibody. Shown is the relative binding to vitronectin of preformed pro-uPA-uPAR complexes in the presence of competitors as compared to the binding of pro-uPA-uPAR alone. 
$A$

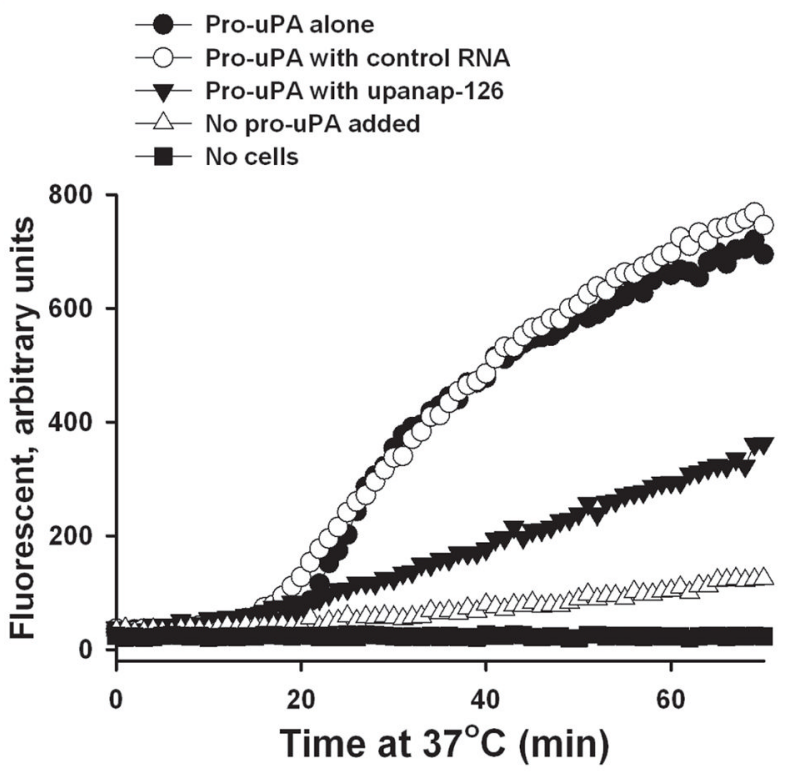

C
$B$
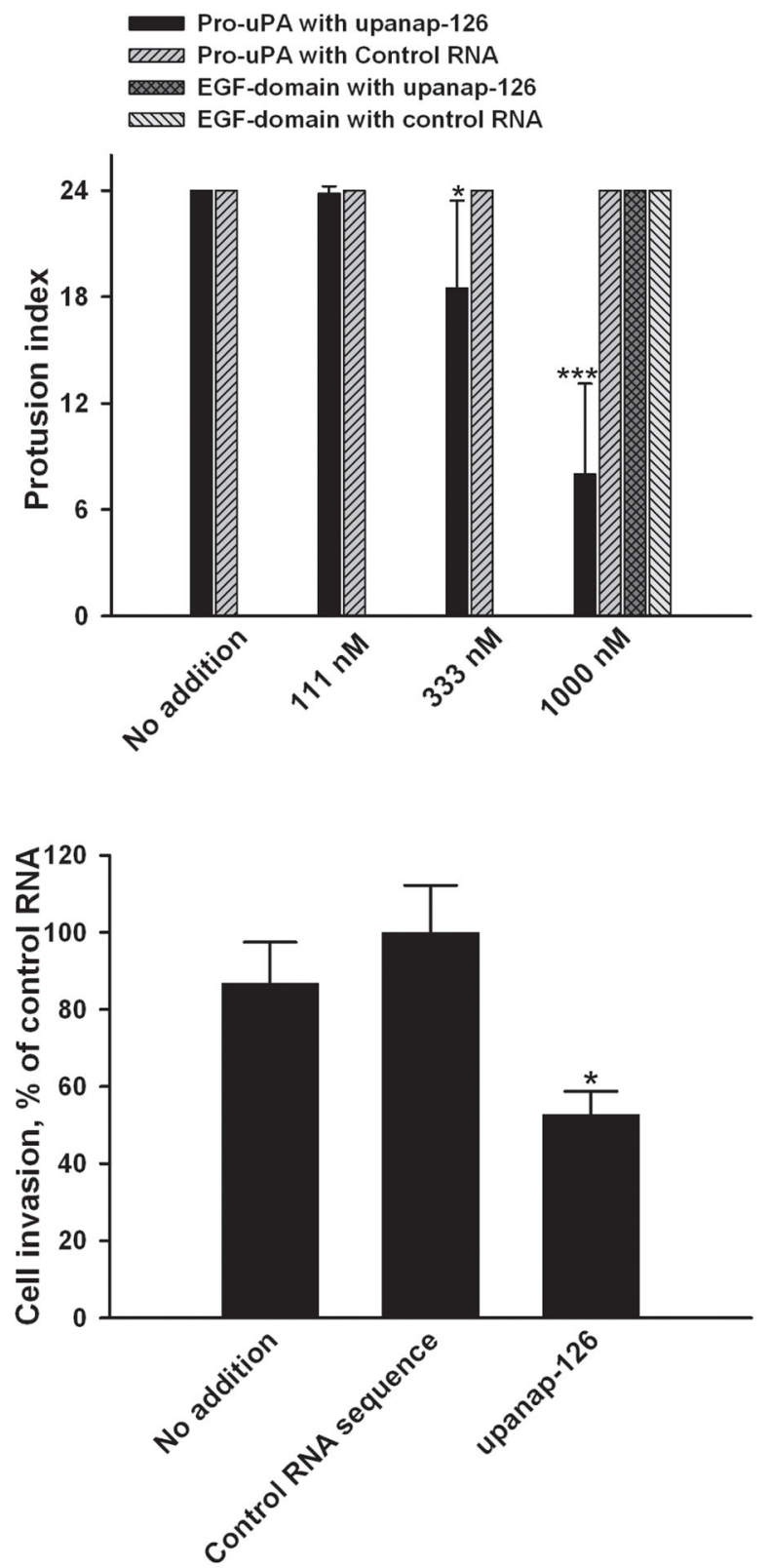

FIGURE 4. Effects of upanap-126 on uPA-dependent events in cell cultures

$\boldsymbol{A}$, Cell-surface dependent plasminogen activation was assayed using acid-washed U937 cells distributed into 96-well plates. Plasminogen $(200 \mathrm{nM})$ and $a_{2}$-antiplasmin $(400 \mathrm{nM})$ was added to cells prior to addition of $1 \mathrm{nM}$ pro-uPA, which had been pre-incubated alone or with aptamers $(500 \mathrm{nM})$ as indicated. The fluorogenic plasmin substrate VLK-AMC was added at $200 \mu \mathrm{M}$ and fluorescence monitored once a minute. $\boldsymbol{B}$, Pro-uPA-dependent lamellipodia formation in HEK293 cells expressing human uPAR $\mathrm{W}_{32 \mathrm{~A}}$ was analysed by plating the cells onto vitronectin-coated glass coverslips. At the day of experiment, $20 \mathrm{nM}$ pro-uPA or EGF-domain along with upanap-126 or control RNA sequence, at final concentrations indicated under the bars, was added to the cells. After a 24 hour incubation, evaluation of lamellipodia formation was carried out by assigning the number 0 (no 
lamellipodia-positive cells present) or 1 (at least one lamellipodia-positive cell in field) to 6 randomly chosen fields for each experimental condition. The protrusion was defined as the combined score obtained from 4 independent researchers for all fields of the samples in question (range 0-24). $\boldsymbol{C}$ and $\boldsymbol{D}$, Effects of upanap-126 on the amount of active uPA generated in cell culture and on cell invasion were assessed using the PC-hi/diss cell variant expressing high amounts of pro-uPA. C, PC-hi/diss cells were grown in the presence of 0.5 $\mu \mathrm{M}$ upanap-126 or control RNA sequence. After 48 hours, samples of conditioned medium were collected and analysed by reducing SDS-PAGE and immunoblotting using anti-uPA polyclonal antibody F1609. Single-chain pro-uPA runs as a 54,000 Da band whereas twochain active uPA runs as two bands at 34,000 Da (SPD) and 20,000 Da (ATF). $\boldsymbol{D}$, In Matrigel invasion assays, PC-hi/diss cells were allowed to invade through the matrix barrier in the absence or presence of upanap-126 or control RNA $(1 \mu \mathrm{M})$, towards conditioned medium from chicken embryonic fibroblasts. The data are presented as percentage of invasion in the presence of control RNA sequence and are means \pm SEM. *, $P<0.05$, twotailed Student's $t$-test. ***, $P<0.001$, two-tailed Student's $t$-test. 
A

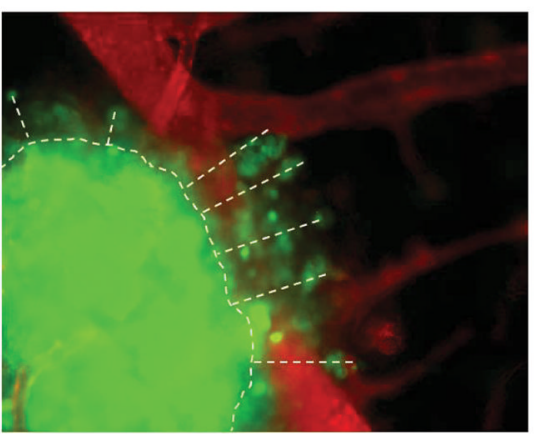

Control RNA sequence

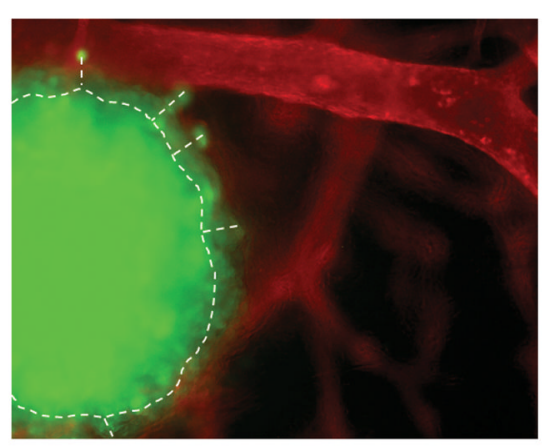

Upanap-126
B

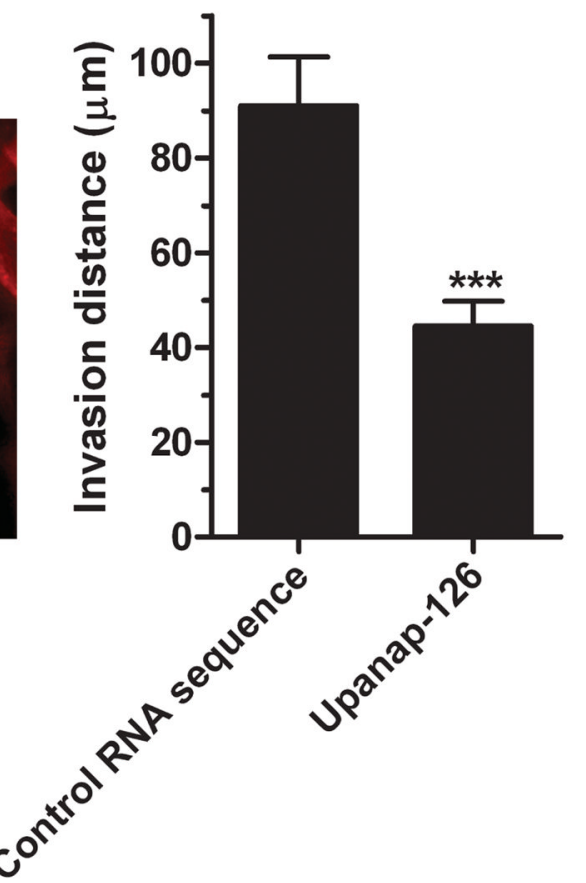

FIGURE 5. Upanap-126 inhibits the invasion of PC-hi/diss cells in the intramesodermal chicken embryo assay

$\boldsymbol{A}$, CellTracker labelled PC-hi/diss cells (green) were injected into the CAM mesoderm of chick embryos. Developing microtumours were treated topically with control RNA sequence or upanap-126 (25 $\mu \mathrm{l}$ of $5 \mu \mathrm{M}$ solution). Rhodamine-conjugated LCA was injected to highlight the CAM vasculature (red). Portions of the CAM containing microtumours were excised and images were digitally acquired at original 100x magnification. Microtumour borders and invasion distances are indicated by white dashed lines. B, Quantification of invasion was performed in digitally captured images by averaging the five longest distances of cell invasion for each microtumour. Data are presented as percentage of PBS control $(100 \%)$ determined for 15-18 individual microtumours per treatment variable and are means \pm SEM. ***, $P<0.001$, two-tailed Student's $t$-test. 
$A$

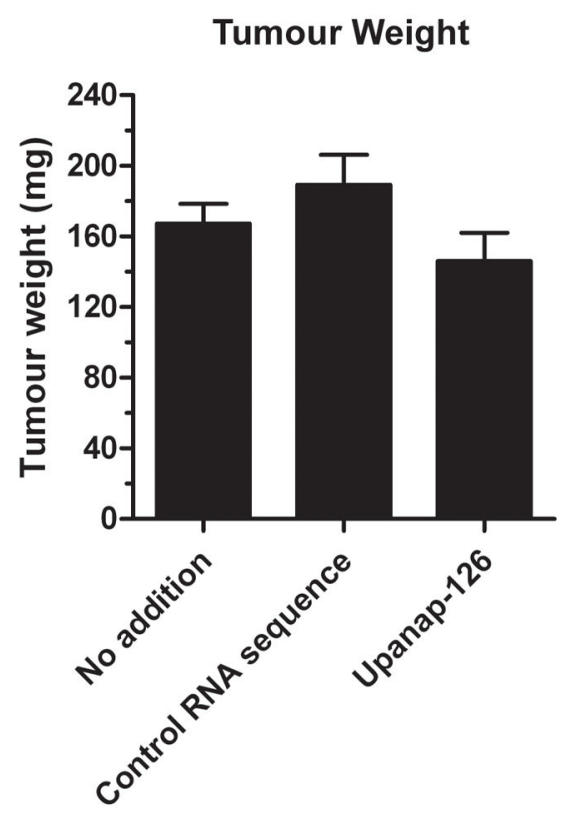

B

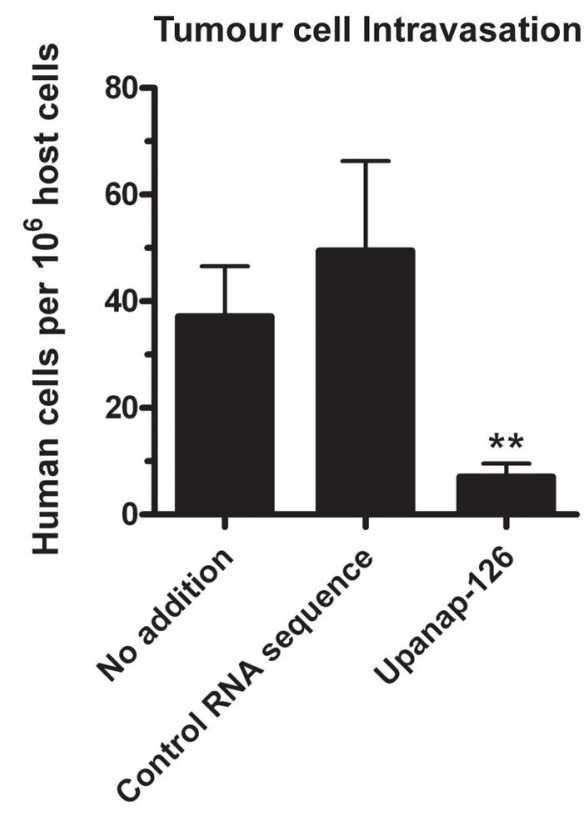

FIGURE 6. Upanap-126 inhibits PC-hi/diss cell intravasation

PC-hi/diss cells $\left(2 \times 10^{6}\right)$ were grafted onto the CAM of day 10 chicken embryos. On day 2 and 4 following cell grafting, the developing primary tumours were treated topically with $100 \mu \mathrm{l}$ of $2.5 \mu \mathrm{M}$ control RNA sequence, upanap-126 or vehicle (DPBS supplemented with $5 \%$ DMSO). On day 7 , the primary tumours were excised and weighed $(A)$. Intravasation of PC-hi/diss cells in the presence of inhibitors was quantified in portions of the distal CAM by quantitative $A l u$-qPCR $(\boldsymbol{B})$. Data are presented as number of human cells identified within $10^{6}$ chicken cells in the CAM tissue and are means \pm SEM. ${ }^{* *}, P<0.01$, two-tailed Student's $t$-test. 
TABLE I

Overview of enriched RNA sequences after selection against human pro-uPA. The sequences of

unique variable regions obtained after 12 rounds of selection are shown as well as their abundance among the 84 sequenced clones.

\begin{tabular}{|c|l|c|c|}
\hline Clone & Sequence of variable region & $\begin{array}{c}\text { Abundance among sequenced } \\
\text { clones (\%) }\end{array}$ & Inhibitory in activity assay $\boldsymbol{a}$ \\
\hline 101 & UUAUCGUACCGUGCUGUGGUUAACGAUAUCUACUC & 1.8 & No \\
\hline 108 & GUUCCUGGACCGCGCUGUGGCCAGGAUCAUCAAAU & 1.8 & No \\
\hline 126 & CAUUCGCACGCUGUGUGGGGAUUAGUCCCGAUGUU & 50.9 & Yes \\
\hline 130 & UGGCAUACCGAUACUGUGGUUAUGAGAUUUGCAGC & 1.8 & No \\
\hline 201 & GGCGUACUGCGCUGUAGUUGCACCAUUACAAGAUC & 3.5 & No \\
\hline 226 & UAUCGAAUUGAUAACCUUACGCGAGAGCGUAGUUC & 24.6 & Yes \\
\hline 231 & CAUGCAUUGCGGGAGCGCUAGCUCCUCAGGUACUA & 3.5 & No \\
\hline 246 & UGCUCACCGCGCUGUGGUCGAGCAAUGCAUUAUAC & 8.8 & No \\
\hline 250 & ACUUUCGAAGGCCGAGUGCUGUCGAAGGGACAUUA & 3.5 & \\
\hline
\end{tabular}

${ }^{a}$ Unique sequences were screened for inhibitory function in a coupled plasminogen activation assay (see Figure 1). 